\title{
Fee hunting in the Texas Trans Pecos area: $A$ descriptive and economic analysis
}

\author{
LARRY D. BUTLER AND JOHN P. WORKMAN
}

\begin{abstract}
Authors are regional range conservationist, Soil Conservation Service, West National Technical Center, 511 NW Broadway, Portland, Oregon 97209-3489; and professor, Range Science Department, Utah State University, Logan 84322-5230.
\end{abstract}

\begin{abstract}
Previous studies of fee hunting have focused only on fee-hunting ranches with little consideration given to ranches that choose not to operate fee-hunting enterprises. Our study compares feehunting with non-fee-hunting ranches. The most important reasons given for engaging in fee hunting were increased income, trespass control, and prevention of nuisance requests for free hunts. The most important reason offered for choosing not to have fee hunting was to keep the ranch available for hunting by family and friends. The potential exists for a large expansion of private land fee hunting by current non-fee-hunting ranches. Ranchers with fee hunting were more likely to manage the grazing resources, wildlife population, and wildlife habitat than non-fee-hunting ranchers. The typical hunting enterprise in the Texas Trans Pecos area provided a total annual net revenue of about $\$ 7,900$. Average annual net grazing returns per livestock animal unit were smaller on fee-hunting ranches but fee-hunting revenue offset the difference. The fee-hunting enterprises also reduced risk by providing a second source of cash returns.
\end{abstract}

Key Words: range recreation, mule deer, net returns, multiple use.

Wildlife populations are dependent upon the land manager's decisions to provide and maintain suitable habitat. In states with mostly private lands, these populations are dependent upon the private landowner (Dill et al. 1983). Clawson (1978) contends that unless owner-managers perceive some direct economic benefit, they will have little incentive to protect and support wildlife.

As ranching enterprises are adapting to survive in today's economic environment, managers must evaluate all ranch resources, including wildlife populations. These wildlife resources must be economically competitive with other ranch production possibilities for the landowner to commit time, labor, and money to wildlife enhancement (White 1986).

Ranchers examining their options for diversifying are considering the alternative of supplying a quality place to hunt (White 1986). Fee hunting has occurred in Texas since the passage of stringent trespass laws in 1925 (Thomas 1966), which transferred control of access to game to the landowner.

Sargent et al. (1958) gave a general idea of the types of hunting lease arrangements used in Texas and the range of resulting income. They called for research to determine the landowners' actual costs of habitat improvement and preservation, crop losses, and reduced livestock production resulting from increased emphasis on wildlife production. They argued that these costs must be related to expected income from hunting leases and expected satisfactions obtained from the enjoyment of wildlife.

Comprehensive economic studies concerning fee hunting are few (Steinbach 1988). Most of the literature has dealt with fee hunting's history and rationale (Jordan and Workman 1989). Ramsey (1965) and Forrest (1968) conducted research on white-tailed deer (Odocoileus virginianus) fee hunting in Texas. Recent research findings have been reported for Utah (Jordan and Workman 1989); Texas (Steinbach 1988, Glover and Conner 1988, Butler 1990, Butler 1991, Cohen 1991); New Mexico (Morgan 1988); California (Fitzhugh 1988); Oregon (Butler 1990); and Montana (Lacey et al. 1988).

Most of the previous research has described and analyzed the fee hunting situation based on examination of only those ranches with fee hunting. With the exception of Butler (1990) and Butler and Workman (1991), ranches with and without fee-hunting enterprises have not been compared.

\section{Objectives}

The objectives of the study were: to describe current fee-hunting enterprises in the Trans Pecos area; to make comparative economic analyses of ranches with and without fee-hunting enterprises; and to make comparative analyses of range management for livestock and wildlife on ranches with and without fee-hunting enterprises.

\section{Methods}

\section{The Study Area}

The study was conducted in the Trans Pecos area of Texas (Fig. 1). Over $90 \%$ of this area is rangeland (SCS Pecos Area Staff 1985).

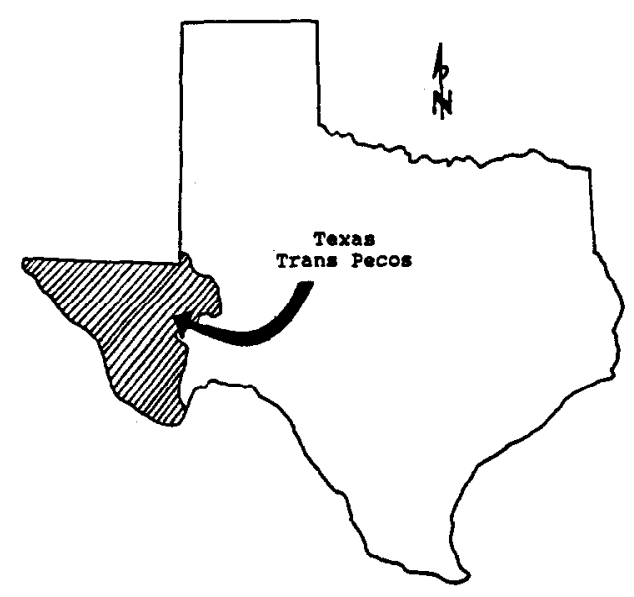

Fig. 1.The study area, the Texas Trans Pecos. 
The Trans Pecos includes 4 vegetative zones: Desert Shrub, Desert Grassland, Mixed Prairie, and Mountain Savannah. Elevation ranges from 671 to 2,667 meters and topography varies from nearly level areas along the Rio Grande and Pecos River flood plains to very steep mountain slopes. Climate is variable depending mostly on elevation. Annual precipitation ranges from about 15 centimeters along the Rio Grande to 46 centimeters in the higher mountains.

\section{Data Collection}

Data were collected by mail questionnaires and personal interviews. All data were pertinent to calendar year 1988. Mail questionnaires were sent to all ranch owners and/or operators with at least 200 hectares of rangeland. The mail survey was conducted in early 1989, utilizing the Total Design Method (Dillman 1978). The original mailing lists contained $\mathbf{4 4 5}$ names and addresses. Removal of nondeliverable surveys, deceased individuals, nonrangeland owners, and individuals who had sold their ranches reduced the total population of interest to 347 .

Seven percent of these 347 individuals responded by stating that they chose not to complete the questionnaire while $130(38 \%)$ completed questionnaires were received, resulting in a $45 \%$ total response rate.

Telephone surveys were conducted to check for nonresponse bias. Ten percent of the nonrespondents ( 20 individuals) were randomly selected for the follow up survey. A series of key questions from the original mail questionnaires were asked. Based upon an analysis of mean and median values it was concluded that there were no significant differences between the mail questionnaire respondents and nonrespondents. Therefore study results can be considered as representative of the total population.

Personal interviews were conducted in the summer of 1989. Respondents to the mail questionnaire were categorized based upon their responses. Ranchers that indicated they had a huntable population of mule deer (Odocoileus hemionus) and a fee-hunting enterprise were placed in the "with fee hunting" group while those with a huntable population of mule deer and no fee hunting were placed in the "without fee hunting" group. Ranchers without a huntable population of mule deer were excluded from the study in order to compare only those ranchers that actually had the option to have mule deer fee hunting.

Ranchers from the with and without fee hunting groups were then randomly selected for personal interviews. Useable interviews were conducted with 25 ranchers with fee hunting and 19 ranchers without fee hunting.

Interview data were used to develop typical enterprise budgets for the 2 groups. These budgets consisted of revenues and costs from the grazing enterprise and hunting enterprise. Grazing revenue consisted of livestock sales and grazing leases. Hunting revenue consisted of only mule deer hunting fees. Only variable costs were considered in the budgets since the decision to operate an enterprise in the short-run is driven by the ability to at least cover variable costs. Owner/manager labor and land costs (mortgage and lease payments) were treated as fixed costs. Net return above variable costs per livestock animal unit was used as a standard of comparison between the 2 groups.

\section{Data Analysis}

Frequencies, means, $t$-tests, and likelihood ratio Chi-square $\left(\mathrm{G}^{2}\right)$ statistics were computed with the SAS System statistical package. For nominal categorical data the $G^{2}$ likelihood ratio test was used to determine if a relationship existed between the variables. Odds ratios (95\% confidence interval) were calculated to determine the magnitude and direction of the relationships.

The $t$-test was used (95\% confidence level) to test for differences of means of normally distributed data. Data were tested for nor- mality utilizing the SAS univariate procedure. When a data distribution failed the normality test, data were normalized through log transformation prior to conducting the t-test.

\section{Results and Discussion}

\section{Mall Questionnaires}

Data from the mail questionnaires were used to describe the current fee-hunting enterprises. The average ranch size in the Texas Trans Pecos area was 12,747 hectares (range: 291 to 89,126 ha), consisting of 6,969 hectares (range: 145 to 71,706 ha) owned land, 4,402 hectares (range: 0 to 81,947 ha) leased private land, and 739 hectares (range: 0 to 56,716 ha) leased state land.

Respondents were asked to identify the various sources of ranch income and to indicate the percentage that each source contributed to total gross income. Eighty-five percent of the ranches reported income from livestock sales. Crop sales contributed income to only $4 \%$ while mineral lease revenue was reported by $28 \%$ of the ranches. Sixteen percent of the ranches received income from leasing rangeland to other ranchers. Fee hunting was a source of income for $52 \%$ of the ranches.

The fee-hunting enterprises did not totally exclude non-paying hunters. Sixty-eight percent of ranchers with fee hunting and $84 \%$ without allowed family and friends to hunt on their lands. Nonfamily and nonfriends were allowed to hunt for free on $24 \%$ of the ranches without fee hunting. Twenty percent of the ranches with fee hunting reserved some areas of the ranch and/or some period of the hunting season for these nonpaying hunters.

\section{Reasons Ranchers Chose Not to Have Fee Hunting}

Nonfee hunting ranchers gave a variety of reasons for choosing not to have fee hunting (Table 1). Most (56\%) preferred to keep

Table 1. Reasons given by non-fee-hunting ranchers for chosing not to have a fee-hunting enterprise (\%).

Prefer to keep ranch for family \& friends $(\%)$

Don't want hunters on the ranch

Ranch is not big enough for fee hunting

29

Not enough wildlife

27

Miscellaneous reasons

26

Added income wouldn't offset the costs

15

Don't need the additional income

7

Tried to, but couldn't get hunters

$$
\mathrm{n}=55
$$

their ranch for hunting by their family and friends. About onefourth of the ranchers stated that their ranch was too small for a fee-hunting enterprise. This may be a false perception as all ranches in the survey included at least 200 ha. Twenty-six percent reported that they did not have enough wildlife for fee hunting. The mule deer density in the study area varied from 67 to 1,235 ha per deer (Clark 1988). There are some fee-hunting ranches in the low deer density areas, but their fee-hunting enterprises are small.

The number of ranchers with fee hunting may increase in the future since $9 \%$ of non-fee-hunting ranchers said they planned to start a fee-hunting enterprise. Thirty-two percent without fee hunting were uncertain about initiating fee hunting in the future.

\section{Reasons Some Ranchers Chose to Have Fee Hunting}

Fee-hunting ranchers were asked to indicate the importance of 4 reasons for choosing to have fee-hunting enterprises: to increase income, for trespass control, to prevent hunters from asking for 
Table 2. Percentages of ranchers with fee hunting that reported various levels of importance of reasons for having fee hunting.

\begin{tabular}{lcccc}
\hline \hline Reason & $\begin{array}{c}\text { Very } \\
\text { important }\end{array}$ & $\begin{array}{c}\text { Somewhat } \\
\text { important }\end{array}$ & $\begin{array}{c}\text { Not } \\
\text { important }\end{array}$ & $\begin{array}{c}\text { Does not } \\
\text { apply }\end{array}$ \\
\hline & -69 & 26 & 2 & 3 \\
Increase income & 69 & 34 & 6 & 42 \\
Trespass control & 18 & 20 & 25 & 50 \\
$\begin{array}{l}\text { Offset forage loss } \\
\text { Prevent hunters from } \\
\text { asking for free hunts } \\
\text { n=65 }\end{array}$ & 32 & 34 & 14 & 20 \\
\hline
\end{tabular}

permission to hunt for free, and to offset of livestock forage to wildlife. As shown in Table 2, increased income was the most important reason followed by prevention of hunters from asking for free hunts.

\section{Description of Fee-Hunting Enterprises}

The average fee-hunting ranch was larger than the average nonfee-hunting ranch (Table 3). $T$-tests were conducted after log transformation of the data to achieve normality. The average number of hectares for ranches with hunting enterprises was statistically larger than ranches without hunting enterprises $(t=-4.14, \mathrm{df}=127$, $p=0.0001$ ). When ranch size was calculated as average total

Table 3. Comparison of ranch characteristics between ranches with and without fee-hunting enterprises in the Texas Trans Pecos.

\begin{tabular}{lrrr}
\hline \hline & & with & without \\
\hline Total hectares & mean & 16,525 & 8,768 \\
& $\mathrm{n}$ & 66 & 63 \\
Owned hectares & mean & 9,183 & 4,675 \\
& $\mathrm{n}$ & 66 & 63 \\
Total private & mean & 13,558 & 8,677 \\
hectares & $\mathrm{n}$ & 66 & 63 \\
Total livestock & mean & 440 & 245 \\
animal units & $\mathrm{n}$ & 61 & 58 \\
\hline
\end{tabular}

animal units, the ranches with hunting enterprises were almost twice as large as those without.

\section{Huntable Populations and Fee Hunting}

Ranchers were asked to identify the wildlife species present in huntable numbers on their ranch. They were also asked to identify the species for which hunters paid access fees to hunt on their lands.

Table 4. Percentages of Texas Trans Pecos ranchers with huntable populations and with fee hunting by species.

\begin{tabular}{lcc}
\hline Species & $\begin{array}{c}\text { Ranches with huntable } \\
\text { population }\end{array}$ & $\begin{array}{c}\text { Ranches with } \\
\text { fee hunting }\end{array}$ \\
\hline & 79 & 35 \\
Mule deer & 28 & 17 \\
Antelope & 59 & 12 \\
Javelina & 89 & 21 \\
Scaled quail & 78 & 13 \\
Mourning dove & 81 & 8 \\
Coyote & 18 & 9 \\
Aoudad sheep & & \\
$\quad \mathbf{n}=130$ & & \\
\hline
\end{tabular}

Table 4 shows the percentages of ranches with huntable populations and the percentage of ranches with fee hunting for each species. Seventy-nine percent of the ranches reported a huntable population of mule deer. Thirty-five percent had fee hunting for mule deer. Thus some ranchers were not utilizing huntable populations of wildlife on their ranches and these wildlife represent a potential for expansion of fee hunting.

It cannot be assumed that all ranchers with huntable populations could have a fee-hunting enterprise for all these species. Some ranches include animals such as javelina (Tayassu tajacu), scaled quail (Callipepla squamata), and coyote in their fee-hunting package for mule deer or antelope hunters. Some constraints are beyond their control. Due to variable rainfall in the Texas Trans Pecos region the numbers of mourning dove (Zenaida macroura) or scaled quail may be too variable over time to plan a fee-hunting operation. State game regulations may constrain ranchers'abilities to have a fee-hunting enterprise. For example, antelope permits are allocated to the landowners based upon an annual aerial census and ranchers cannot be sure how many permits, if any, they will receive.

\section{Fee Hunting Gross Revenues}

Ranchers with fee hunting were asked to list the prices they charged for the right to hunt various wildlife species. Ranchers charged for hunting rights by the day, week, or hunting season and by the animal for exotic species.

Charging by the season was the most common pricing method for mule deer hunting as $84 \%$ of mule deer fee-hunting ranchers priced their hunts by the season. The average season price was $\$ 828$ per hunter. The minimum price quoted was $\$ 300$ and the maximum was $\$ 1,500$. Other ranchers charged by the week for mule deer hunting with an average of $\$ 1,183$ per hunter per week. The weekly rates varied from a minimum of $\$ 1,000$ to a maximum of $\$ 1,500$. The average gross revenue per ranch for mule deer hunting was $\$ 11,245$, ranging from $\$ 1,500$ to $\$ 37,500$.

Twenty-one ranchers charged fees for antelope hunting rights. The average fee was $\$ 570$ per hunter per season with a range from $\$ 100$ to $\$ 1,000$. Fifteen ranchers received fees for scaled quail hunting. Several reported that quail hunting was included as a bonus in their mule deer hunting rights. The average price for one day's quail hunting was $\$ 34$ with a range of $\$ 25$ to $\$ 50$ per day. Season quail hunting rights averaged $\$ 118$ per person with a range of $\$ 38$ to $\$ 300$. Some ranchers sold mourning dove hunting rights that allowed hunting in any area of the ranch while others specified stock watering ponds or windmill sites. Hunting rights for mourning dove varied from $\$ 13$ per hunter day to $\$ 1,000$ per windmill per season. The average price for a season of dove hunting was $\$ 233$ per person.

The aoudad or Barbary sheep (Ammotragus lervia) is an introduced exotic that free ranges in many of the mountain ranges of the Texas Trans Pecos. There is no specified hunting season for these sheep and they are considered the private property of landowners where they live. Aoudad sheep hunting is generally sold on a per animal basis. The average price received for an aoudad sheep hunt was $\$ 881$ per animal with a range of $\$ 250$ to $\$ 2,000$.

\section{Facilities and Services}

There was a variety of services and facilities provided to hunters. No statistically significant relationship was found between the fee charged and number or combination of facilities and services for mule deer hunting. Table 5 shows the percentage of ranches with mule deer fee-hunting enterprises that provided specific facilities and/or services.

\section{Wildife Management}

Ranchers were asked to list specific wild life management practices utilized on their ranches. The results are listed in with and without fee-hunting categories (Table 6). 
Table 5. Percentages of Texas Trans Pecos ranchers with mule deer fee hunting that provided specific hunter facilities and/or services.

\begin{tabular}{lc}
\hline \hline $\begin{array}{l}\text { Facility or service provided to } \\
\text { to hunters }\end{array}$ \\
\hline & $(\%)$ \\
Guides & 36 \\
Meals & 20 \\
Horses & 16 \\
Vehicles & 27 \\
Water & 69 \\
Lodging & 78 \\
Firewood & 53 \\
Firing range & 31 \\
Campsite with electricity & 22 \\
Campsite without electricity & 22 \\
Care of trophy & 4 \\
Field dress game & 18 \\
Miscellaneous & 22 \\
$\quad$ n $=45$ & \\
\hline
\end{tabular}

The practices of adjusting livestock numbers, adjusting livestock grazing pattern, and adjusting wildlife harvest were clustered together and the responses of ranchers with and without fee hunting were tested with a likelihood ratio chi-square. A relationship existed $\left(G^{2}=7.8, p=0.005\right)$ and the data indicated that ranchers with fee hunting were almost 3 times more likely to adjust livestock numbers, adjust livestock grazing patterns, or adjust the wildife harvest than were ranchers without fee hunting (odds ratio $=2.7$, $95 \%$ confidence interval $=1.3$ to 5.6 ).

\section{Personal Interviews}

\section{Ranch Income Statements}

Ranchers were asked to provide revenues and costs from their grazing and hunting enterprises. The grazing enterprise was defined as the ranch-owned cattle operation and/or ranch grazing lease. The hunting enterprise consisted of only mule deer hunting. Revenues from separate enterprises were easily identified; however, enterprise costs were often difficult to identify. While some ranchers had a very detailed accounting system, others had not considered costs on an enterprise basis. In all interviews, ranchers successfully separated costs by enterprise.

The FEEDSTORIS micro-computer program for ranch planning (Tanaka et al. 1987) was used as a guideline to develop ranch income statements from rancher questionnaires. Individual ranch income statements were used to develop typical ranch income statements for ranchers with and ranchers without mule deer fee hunting.

\section{Grazing Enterprise Revenue}

As the average fee-hunting ranch was larger than the average ranch without fee hunting, it was not surprising that the average total grazing revenue was larger on fee-hunting ranches $(\$ 87,988)$ than non-fee-hunting ranches $(\$ 77,693)$. Based on these data, it was initially hypothesized that there was no difference between the 2 ranch groups in net grazing return above variable cost per livestock animal unit.

Ranches with fee hunting typically ran 300 to 350 animal units of livestock while those without ran 225 to 300 animal units. Average cash operating costs were $\$ 36,927$ and $\$ 25,274$, respectively, on ranches with and without fee hunting. Grazing enterprise net returns above variable costs were about the same, $\$ 51,061$ and $\$ 52,419$, respectively, for ranches with and without fee hunting.

Average net grazing returns above variable costs per livestock animal unit were $\$ 150$ and $\$ 197$, respectively, on ranches with and
Table 6. Wildlife management practices reported by ranchers with and without fee hunting in the Texes Trans Pecos.

\begin{tabular}{lcc}
\hline \hline & $\begin{array}{c}\text { with } \\
\text { fee hunting }\end{array}$ & $\begin{array}{c}\text { without } \\
\text { fee hunting }\end{array}$ \\
\hline Supplemental feeding & $\ldots \ldots(\%)$ & $\cdots$ \\
Adjust livestock numbers & 33 & 40 \\
Adjust livestock grazing pattern & 34 & 22 \\
Provide water & 34 & 27 \\
Adjust wildlife harvest & 72 & 68 \\
Food plots* & 60 & 27 \\
Brush management** & 5 & 8 \\
Range seeding** & 25 & 16 \\
& 12 & 21 \\
& $\mathrm{n}=67$ & $\mathrm{n}=63$ \\
\hline
\end{tabular}

*Plots not available to livestock.

**Done with consideration for wildlife.

without mule deer fee hunting. There was a significant difference $(\mathrm{t}$ $=1.65, \mathrm{df}=42, \mathrm{p}=0.11$ ) in net grazing return above variable costs per livestock animal unit between the 2 groups. One possible explanation of the higher income per livestock animal unit on non-fee-hunting ranches is that these ranchers have less diversification and concentrate more of their attention, labor, and management on their grazing enterprise.

Hunting Enterprise Revenue

Interviews reported an average mule deer hunting revenue per fee-hunting ranch of $\$ 11,283$, confirming the $\$ 11,245$ average value resulting from questionnaire data. Typical fees were $\$ 750$ to $\$ 1,250$ per hunter and the typical hunting enterprise had 8 to 14 fee-paying hunters per mule deer season.

Typical hunting variable costs totaled about $\$ 3,400$ per ranch per year. Included were: fuel; insurance (personal liability and casualty on property such as hunting cabins); hired labor (guides, cooks, and general labor during the year); repairs (maintenance on cabins, water developments, gates, fences, and roads); supplies (tires, batteries, and groceries for hunter meals); utilities (cabins, camper-trailer hook-ups, and pumping costs for wildlife water); and other expenses (mail, telephone, predator control, trespass control, attorney and accountant fees, supplemental feed, hunting preserve license, and professional dues).

Average net return above variable costs was $\$ 7,893$ per ranch. Fee-hunting ranches had a typical population of 60 to 70 animal units of mule deer. The average net hunting return above variable costs per mule deer animal unit was $\$ 116$.

Since fee-hunting ranches had a lower average net grazing return per animal unit of livestock, it was important to determine if added hunting revenue would offset the lower returns per animal unit from a possibly less efficient livestock operation should a rancher consider adding a hunting enterprise. Adding net hunting revenue to the net grazing revenue, total net return above variable costs was $\$ 58,954$, and average net return per livestock animal unit was calculated at $\$ 183$. This was not significantly different $(t=0.60, \mathrm{df}=$ $41, p=0.55$ ) from the $\$ 197$ per livestock animal unit on the ranches without fee hunting.

If adding fee-hunting could potentially reduce the net return per livestock animal unit, why add a hunting enterprise? One reason is to diversify as a precaution against risk (Castle et al. 1987). The fee-hunting enterprise is a more reliable source of income than the livestock enterprise since a hunting enterprise has an income level that has remained constant (or even increased) over time (Butler 1991).

A second source of cash income is another benefit from fee hunting. Mule deer fee hunting contributed about $10 \%$ of total grazing and hunting receipts on fee-hunting ranches. Hunting fees usually consisted of 2 cash payments. The first payment was usu- 
ally one-half the total fee and was generally collected 6 to 8 months prior to the hunt. The remainder was usually collected during the hunt. In-kind services, such as road repair work, were sometimes substituted for cash payments. Often the in-kind services had a higher value than the hunting fees.

Two ranchers interviewed had negative net returns above variable costs for their hunting enterprises. Both were relatively new enterprises that provided guides, vehicles, meals, and lodging, and had extensive and expensive deer censuses conducted by consulting wildlife biologists.

Ranchers without fee hunting typically had 30 to 40 animal units of mule deer. Given an average potential net return above variable costs of $\$ 116$ per mule deer animal unit, they were foregoing an average increased potential net return of $\$ 3,000$ to $\$ 4,000$. The fact that fee-hunting ranchers, on the average, earned lower net grazing returns per livestock animal unit does not diminish their hunting returns. It only indicates that, on the average, net grazing returns per animal unit could potentially be increased on the fee-hunting ranches.

\section{Conclusions}

The potential for more ranchers to begin a fee-hunting enterprise exists. Since the desire to increase income is the most important reason reported for having a fee-hunting enterprise, it is important that ranchers with fee hunting and those considering the addition of a fee-hunting enterprise evaluate potential management and economic impacts this additional enterprise might have upon existing ranch enterprises.

On the average, fee-hunting ranchers received less net grazing returns per livestock animal unit than did non-fee-hunting ranchers. Ranchers with fee hunting should recognize that the potential for less efficiency in their grazing enterprise exists. Ranchers without fee hunting should recognize that there is a potential to increase total net revenue. Both groups of ranchers should take the necessary management actions to maintain efficiency in all enterprises.

\section{Literature Cited}

Butler, L.D. 1990. Fee hunting on private rangelands in the Texas Trans Pecos and central Oregon. Ph.D. Diss. Utah State Univ., Logan.

Butler, L.D. 1991. White-tailed deer hunting leases: hunter costs and rancher revenues. Rangelands 13:20-22.
Butler, L.D., and J.P. Workman. 1991. A comparison of fee hunting on private rangelands in central Oregon and the Texas Trans Pecos. p. 269-276. In: L.A. Renecker and R.J. Hudson (eds.) Wildlife Production: Conservation and Sustainable Development. Univ. Alaska, Fairbanks.

Castle, E.N., M.H. Becker, and A.G. Nelson. 1987. Farm business management: the decision-making process. Macmillan, N.Y.

Clark, T.L. 1988. Performance report. Big game harvest regulations-mule deer. Texas Parks and Wildlife Department. Austin, Tex.

Clawson, M. 1978. Economic choices of rangeland uses. p. 32-33. In: D.N. Hyder (ed.). Proc. First Int. Rangeland Congr., Soc. Range Manage, Denver, Colo.

Cohen, W.E. 1991. Economic strategies for white-tailed deer and livestock production on central and south Texas ranches. Ph.D. Diss. Utah State Univ., Logan.

Dill, T.0., J. Menghini, S.S. Waller, and R. Case. 1983. Fee hunting for Nebraska big game: a possibility. Rangelands 5:24-27.

Dillman, D.A. 1978. Mail and telephone surveys: the total design method. John Wiley and Sons, N.Y.

Fitzhugh, E.L. 1988. What can we learn from California's ranching for wildlife program?, p. 69-73. In: D. Rollins (ed.), Proc. recreation on rangelands: promise, problems, projections. Soc. Range Manage. Corpus Christi, Tex.

Forrest, N.K. 1968. Effects of commercialized deer hunting arrangements on ranch organization, management, costs, and income-the Llano basin of Texas. M.S. Thesis. Texas A\&M Univ., College Station.

Glover, M.K., and J.R. Conner. 1988. A model for selecting optimal combinations of livestock and deer lease-hunting enterprises. Wildl. Soc. Bull. 16:158-163.

Jordan, L.A., and J.P. Workman. 1989. Deer and elk fee hunting opportunities in Utah: economics and management. Wildl. Soc. Bull. 17:482-487.

Lacey, J.R., S.B. Laursen, J.C. Gilchrist, R.M. Brownson, J. Anzick, and S. Doggett. 1988. Economic and social implications of managing wildlife on private land in Montana. Northwest Sci. 62:1-9.

Morgan, C.H. 1988. Fee hunting on private ranches in New Mexico. M.S. Thesis. New Mexico State Univ., Las Cruces, N.M.

Ramsey, C.W. 1965. Potential economic returns from deer as compared with livestock in the Edwards Plateau region of Texas. J. Range Manage. $18: 247-250$.

Sargent, F.O., C.C. Boykin, O.C. Wallmo, and E.H. Cooper. 1958. Land for hunters - a survey of hunting leases. Texas Game and Fish. September. p. 22-23, 29.

SCS Pecos Area Staff. 1985. Pecos area resource data. USDA. Soil Conserv. Serv.. Pecos, Tex.

Steinbach, D.W. 1988. Economics and operational characteristics of recreational leasing in the Edwards Plateau and Rio Grande Plains of Texas. Ph.D. Diss., Texas A\&M Univ., College Station.

Tanaka, J.A., L.A. Torell, and J.P. Workman. 1987. FEEDSTORIS: a micro-computer program for ranch planning. Rangelands 9:51-55.

Thomas, J.W. 1966. Deer and the commercialized hunting system in Texas, p. 42-54. In: Proc. The white-tailed deer: its problems and potentials. Texas A\&M Univ., College Station.

White, R.J. 1986. Big game ranching in the United States. Wild Sheep and Goat Int. Mesilla, N.M. 